\title{
TV/Series
}

$1 \mid 2012$

Les Séries télévisées américaines contemporaines :

entre la fiction, les faits, et le réel

\section{Fiction and Reality in HBO's Treme: A Narrative Alchemy at the Service of Political Truth}

Catherine Dessinges, Dominique Gendrin and Wendy Hajjar

\section{OpenEdition}

\section{Journals}

Electronic version

URL: http://journals.openedition.org/tvseries/1165

DOI: 10.4000/tvseries. 1165

ISSN: 2266-0909

Publisher

GRIC - Groupe de recherche Identités et Cultures

Electronic reference

Catherine Dessinges, Dominique Gendrin and Wendy Hajjar, « Fiction and Reality in HBO's Treme: A Narrative Alchemy at the Service of Political Truth », TV/Series [Online], 1 | 2012, Online since 15 May 2012, connection on 01 May 2019. URL : http://journals.openedition.org/tvseries/1165 ; DOI : 10.4000/tvseries. 1165

\section{(c) () $९$}

$T V /$ Series est mis à disposition selon les termes de la licence Creative Commons Attribution - Pas d'Utilisation Commerciale - Pas de Modification 4.0 International. 
Fiction and Reality in HBO's Treme: A Narrative Alchemy at the Service of Political Truth

Catherine DESSINGES

Dominique GENDRIN

Wendy HAJJAR

\begin{abstract}
Author of the television drama The Wire, David Simon with Eric Overmyer launched a new series entitled Treme on the American channel HBO in April, 2010. Located in the heart of New Orleans, Tremé is a neighborhood known for its unique cultural, social, and historical context. It is the oldest African American neighborhood in the United States, the birthplace of the Black civil right movement in the South and the home of Jazz. Categorized as a drama by David Simon, the series is a work of fiction. Yet it also depicts day-to-day life in New Orleans in the aftermath of Katrina, referencing real events, real people, real places, and real cultural symbols. Relying on the work of Schaeffer and Esquenazi, this article links fiction to reality with an analysis of historical truths though fictional characters' narratives. With this methodology, we examine the film-makers' perspective, and uncover the political intentionality of the series as an act of denunciation against the dysfunctions of the local, state, and federal institutions in responding to the Katrina catastrophe. The political message of the series is also an act of testimony and homage about the daily lives and struggles of New Orleanians in a post-Katrina era.
\end{abstract}

Tn summer 2008 HBO (Home Box Office Television) confirmed that David Simon, who had just completed the $5^{\text {th }}$ season of The Wire (2002-2008), would develop a pilot for another series for the network set in the Faubourg Tremé neighborhood of New Orleans. Located in the heart of New Orleans, Faubourg Tremé is the oldest African American neighborhood in the United States, the birthplace of the Black civil rights movement in the South and the home of Jazz. The Treme series references this unique cultural, social, and historical context.

The series premiered on HBO April 11, 2010 with an 80-minute pilot episode, the first of a 10 episode season ${ }^{1}$. Season 1 , episode 1 begins in October, 2005, a few weeks after Hurricane Katrina (8/29/05) flooded New Orleans leaving parts of the city under water for much of the month of September. The first season ends soon after Mardi Gras 2006, some six months after the flood.

Categorized as a drama by its producers, Treme is a work of fiction.It centers on the realities of post-Katrina New Orleans, focusing

${ }^{1}$ About the Show, < http://www.hbo.com/Treme/about/index.html>, consulted May 23, 2010 
on its music scene, its political controversies, and the struggle to return to a system that was corrupt at best before the 2005 devastation. It explores political, social, and cultural issues affecting the city, such as political corruption, the public housing controversy, a crippled criminal-justice system, and clashes between police and Mardi Gras Indians. It also depicts day-to-day life in New Orleans in the aftermath of Katrina, referencing real events, some real people, real places, and real cultural symbols

The fundamental characteristic of the series lies in the realism of its scenes and the narratives grounded in historical fact. In this article, we want to demonstrate how the communicative nature of the series is grounded in the factual rigor of the events represented. Thus, we uncover how the series reflects what the producers want to communicate about the city of New Orleans and its resident. Their intent emerges out a strong desire to engage the viewers in a critical analysis of the city's recovery after Hurricane Katrina. For New Orleans viewers in particular, the everyday realities of the series' characters should resonate with their own challenges in rebuilding their lives after the storm. The viewers should also find, in their need to overcome their own challenges, a strong form of denunciation and political condemnation of the breakdown of American institutions, and validation of their own evaluations of the causes of the devastation. In essence, the series should serve as a metaphor of their own struggle and desire to survive the catastrophy.

To present and analyse the underlying political messages of the series, we rely on the work of Jean Marie Schaeffer ${ }^{2}$, Jean Pierre Esquenazi ${ }^{3}$, and John Corner ${ }^{4}$ Their writings on fiction contribute to our understanding of the intricate link between fiction and reality and the underlying importance of the realities' presence in the fictional narrative. In the next section, we articulate the relationship between fiction and reality and how this relationship applies to the context of Drama and Realism in the Treme series.

\section{Theoretical framework: fiction and reality}

The mix of fiction and reality in the Treme series has been much debated by New Orleanians. After viewing the first episode of the series, and attentive to the need to provide an accurate depiction of their city, the people of the real Faubourg Tremé remarked on the

\footnotetext{
${ }^{2}$ Jean-Marie Schaeffer, Pourquoi la fiction?, Paris, Le Seuil, 1999.

${ }^{3}$ Jean-Pierre Esquenazi, Sociologie des œeuvres. De la production à l'interprétation, Paris, Armand Colin, 2007 et La vérité de la fiction, Paris, Hermès, Lavoisier, 2009.

${ }^{4}$ John Corner, Presumption as theory: 'realism' in television studies, Screen 33, Spring 1992 pp. 97-102
} 
discrepancies revealed in the series 5 . Still, others praised the series for finally "getting it right" after much misrepresentation of the city in commercial films and television programs. Local television critics and newspaper reporters praised Treme for capturing something of the essence of the city ${ }^{6}$.

Even though both share some elements of reality, fiction and reality constitute two different arenas. Fiction is, literally, another world, a world which abides by other rules. In his book Univers de la fiction (The World of Fiction), Thomas Pavel refers to a potential world that is a fictional world conceptualized as a dual structure resulting from the combination of a fictional universe and a real world that provides the basis on which fiction is to be understood 7 . According to Pavel, a fictional narrative implies a respect for the necessary conventions of the genre: it must be an imitation of the real or imaginary stories generally analogous to a real basis, and its expression must be guaranteed by likely fictional characters. According to Schaeffer, a fictional story is a de facto model of the real world, relying on the imitation-semblance dichotomy ${ }^{8}$. That is, to put it in Erving Goffman's terms, a creation founded on actual situations and "the proposition that invented narratives can represent plausible behaviors and events in the real world9".

Justifying their auctorial intention, David Simon and Eric Overmyer remind us that Treme is a drama, not a documentary. That is to say that the series is a work of fiction and its attention to facts is intended to make it believable. Indeed, according to Aristotle, fiction "is not to say what happened, but what would have happened, what was possible according to some necessity or believability10". This definition implies that believability must be understood as what is probable in the context of reality; it is linked to the probable, that is, to a certain representation of what is possible or plausible in the context

\footnotetext{
${ }^{5}$ Campbell Robertson, "Gathering to watch their city's star turn”, The New Orleans Journal/The New York Times (April 10, 2010),

http://www.nytimes.com/2010/04/13/us/13orleans.html?_r=1\&hpw, consulted November $3,2011$.

${ }^{6}$ Dave Walker, "HBO's Treme finally gets New Orleans right", The Times Picayune (April o9, 2011), http://www.nola.com/treme-

hbo/index.ssf/2010/04/treme is probably as good as i.html, consulted November 3, 2011. "David Simon's Treme captures New Orleans", http://www.bestofneworleans.com /gambit/david-simons-treme-captures-new-orleans/Content?oid=1278312, consulted November 3, 2011.

7 Thomas Pavel, Univers de la fiction, Paris, Le Seuil, 1988.

${ }^{8}$ Schaeffer, p. 147 et p. 218.

${ }^{9}$ Esquenazi, 2009, p. 192.

${ }^{10}$ Aristotle, La poétique, Paris, Ed. and trans. Rosalyne Dupont-Roc y Jean Lallot, Le Seuil, 1980, [p. 36-65].
} 
of reality ${ }^{11}$. Michael Riffaterre ${ }^{12}$ adds that the importance of believability lies in its ability to always combine signs of fiction with a convention of truth, i.e., signs of plausibility which ensures that viewers will react to the story as if it were true. Finally "the veracity of a historical narrative is what distinguishes it from a fictional story ${ }^{13}$ ": whereas the story is a narrative of real events, fiction is a narrative of imagined events grounded in reality whose believability constitutes the issue of credibility, according to Daniel Pernot ${ }^{14}$. Sometimes, the boundaries between fiction and reality are so blurred that it is difficult for the viewers to distinguish them. For example, referencing the Wire, C. W. Marshall and Tiffany Potter argue that David Simon's earlier series "works to counfound the line between truth and fiction. It screams of verisimilitude." 15 Regarding Treme, David Simon confirms his willingness to document the fictional nature of the series when he states that "the show is not a documentary but he and his creative staff have made relentless efforts to insure that the city is as accurately depicted as possible ${ }^{16}$ ". According to its creators, the relationship between fiction and truth is at the heart of the series' creative process.

In his seminal book, The Truth about Fiction, Jean-Pierre Esquenazi highlights the process of evaluation and authenticity of fictional work in relation to the concept of truth. He states that "Fictional truth bears on the understanding that this fiction offers on our real world 17 ". The author distinguishes in this regard fictional truths that are felt realities, experienced as possibilities or accurate exemplifications of reality in the intimate confines of the interpreter. Conversely, historical truths allow viewers to review and judge fiction in its relationship with the historical context in which it is set ${ }^{18}$. These latter truths refer to the real basis of the story, their purpose, and the significance of the events, actions, and characters throughout the narrative ${ }^{19}$. To begin, Treme, while being a fully-scripted drama shares

${ }^{11}$ Andrée Mercier, "La vraisemblance: état de la question historique et théorique” Temps zéro. Revue d'étude des écritures contemporaines, $\mathrm{n}^{\circ} 2,2009$,

<http://tempszero.contemporain.info/document393>, consulted February 22, 2011.

12 Michael Riffaterre, Fictional Truth, Baltimore, Johns Hopkins University Press, 1990.

13 Esquenazi, 2009, p. 45.

14 Daniel Pernot, "Vraisemblance", in Paul Aron, Denis Saint-Jacques et Alain Viala

[dir.], Le dictionnaire du littéraire, Paris, Presses universitaires de France (Quadrige), $2 e$ édition revue et augmentée, (2004) [2002], [p. 646-647].

15 C. W. Marshall and Tiffany Potter, "I am the American dream': Modern urban tragedy and the borders of fiction", in Tiifany Potter and C. W. Marshall (eds.), The Wire: Urban decay and American television, New York, The Continuum International publishing Group, Inc., (2009), [p. 1-14].

16 Alicia Duplessis Jasmin, Down in the 'Treme',

http://tulane.edu/news/newwave/110110 treme.cfm?RenderForPrint=1, consulted November 30, 2010.

${ }^{17}$ Esquenazi, 2009, p. 183

${ }_{18}$ Schaeffer, p. 218-219.

${ }^{19}$ Esquenazi, p. 38. 
some overlap with historical truth in that it is about real people. Moreover, the creators of the program set out to document the experiences of an entire cultural community. To that end, a high percentage of the cast is made up of local residents. And local artists, authors, musicians and film makers have served as inspiration, consultants, and writers on the program. For example, the character of D.J. Davis, played by Steve Zhan, is based on New Orleans native Davis Rogan, who also had a small part on the program as a piano player featured in seven episodes. Treme shares also some overlap with reality in that it is also about real events, situations, and opinions that have historically marked the city in the aftermath of Katrina. For example, the people of New Orleans were vindicated in their conviction that the Army Corp of engineers had failed to strengthen the levees ${ }^{20}$.

Keeping in mind this link between historical truth and fiction, the creators portray the likeness of the impact of Katrina on New Orleans, articulating clearly what Esquenazi has called historical truth as the real foundation to a fictional, yet relative truth. In an interview with the Times Picayune (2010), Simon expresses this with the following:

By referencing what is real, or historical, a fictional narrative can speak in a powerful, full-throated way to the problems and issues of our time. And a wholly imagined tale, set amidst the intricate and accurate details of a real place and time, can resonate with readers in a profound way. In short, drama is its own argument ${ }^{21}$.

Thus, historical truths ensure the critical readability of fiction and capture the audience's imagination and need for accuracy. This idea is shared by Schaeffer 22 who argues that neither fictional immersion nor emotional investment could exist, i.e. we could not enter into fiction without this connection by which the characters and their fates attract viewers' curiosity and resonate with their real interests. Yet it is only when a fictional story manages to act as a metaphor ${ }^{23}$ or a paraphrase ${ }^{24}$, a facet of the viewer's actual world that

\footnotetext{
${ }^{20}$ Campbell Robertson, "In New Orleans, Elation over Katrina Liability Ruling”, The New York Times (November $19^{\text {th }}, 2009$ ),

http://www.nytimes.com/2009/11/20/us/20orleans.html, consultged November

November 3, 2011.

"Army Corps of Engineers", The New York Times (November 3, 2011),

http://topics.nytimes.com/top/reference/timestopics/organizations/a/army_corps_of_en gineers/index.html?inline=nyt-org, conlusted November 3, 2011.

${ }^{21}$ HBO's 'Treme' Creator David Simon Explains It All for You”, The Times Picayune April

11, 2010,

http://www.nola.com/tremehbo/index.ssf/2010/04/hbos_treme_creator_david_simon.ht $\underline{\mathrm{ml}}>$, consulted February 22, 2011.

${ }^{22}$ Schaeffer, p. 199.

23 Arthur Danto, "La littérature comme philosophie" in L'assujettissement philosophique de l'art, Paris, Le Seuil, 1983, [p. 205-232].
} 
fictional appropriation works. Fictional appropriation cannot take place without the author's knowledge of the viewers' realities. According to Esquenazi, from the viewers' perspective, the relevance of historical truths depends on the degree of realism used as the basis of the fictional story. In view of the strong relationship that exists between fiction and truth in the Treme series, we consider the series genre as a form of Dramatic Realism. Because Treme is located in a specific time and place, some discussion of the term Dramatic Realism is in order.

Reality television is, of course the newest generic form of unscripted television drama which is highly contrived, nonetheless, using staging and editing to create character and plot lines. Realism, realistic, actuality, naturalism, and docudrama are all terms used to describe a sense of the real in narrative television along with secondary terms like authenticity, verisimilitude and simulation.

In this paper, we rely on John Corner's conception of realism to link the realism of the series to the Political intention of the producers ${ }^{25}$. John Corner has written about the use of realism in television, distinguishing between realism of form and realism of theme. While the first might be more of a verisimilitude: being like the real, the second sense is more referential: being about the real. A useful framework when discussing the ideological constructions of news or documentary forms, for example, when applied to fictional narrative is more concerned with plausibility than factuality. Realism of form includes the creative components of staging, writing, acting, filming and editing. Realism of theme involves analyzing the social and political circumstances, and it suggests a normative dimension to elements such as characterization and action ${ }^{26}$. In Treme Dramatic Realism is achieved through realism of form in casting, writing, and consulting choices made by the creative directors, David Simon and Eric Overmyer. Realism of theme is achieved through the selection of social and political scenarios, relationships and action. It is the latter form of realism that is the focus of this study as it allows us to uncover the intention of the producers through a careful analysis of the political and socio-cultural dimensions of the series.

\section{Methodology}

In the following analysis, we elaborate on what Schaeffer calls the incursion of reality into fiction ${ }^{27}$ that is the manner in which the

\footnotetext{
24 Esquenazi, 2009, p. 154

${ }^{25}$ John Corner, 1992, pp. 97-102.

${ }^{26}$ John Corner, Presumption as theory: 'realism' in television studies, Screen 33, Spring 1992 pp. 97-102.

${ }^{27}$ Schaeffer, p. 142.
} 
process of invention is "affected" by semiotic reference. We apprehend the auctorial project in its historical perspective by exploring the creators' reliance on historical facts. This perspective seeks the authenticity of historical and social everyday facts, whether affective, cognitive or behavioral in fictional representation. Keeping in mind the link between historical truth and fiction, the producers have intended to portray events precisely in a thematic way rather than accurate facts. Thus, we present the incursion of reality into fiction (Schaeffer) by analyzing the historical truths of Treme (Esquenazi) through realism of themes (Corner). In particular, we focus on the residents of New Orleans' outrage at the lack of adequate federal assistance in helping the city during and after Hurricane Katrina and the total breakdown of the city's intitutions, as well as the economic demise of the city in the aftermath of the storm. These broad themes allow us to uncover the political intention of the producers by grouping them into two categories that we label projects. The first is devoted to the political project of the series that denounces the failure and dysfunction of the Bush administration and City Hall in the aftermath of Katrina (section 1); the second focuses on the economic perspectives of individuals who had to struggle to recover their situation (section 2). To be faithful to the intention of the creators who said that they "did not want to editorialize the issues, but let the characters themselves address them" 28 , we present the political and economic projects through a careful analysis of the characters' visual and discursive narratives linking fictional events to actual ones. Specifically, we rely on three types of data: media discourse, a unique process of characterization, and interviews with the creators. The results demonstrate the essential link between fiction and reality to get viewers to access the political intention the producers articulate in their work.

\section{Section 1: The political project of HBO's Treme}

The political project of Treme emerges out of the characters' perspectives as they voice their frustrations, issues and problems, and the strategies they use to deal with the daily exigencies of living in a devastated city. Creators David Simon and Eric Overmyer have been vocal and candid about the writing process and the inspirations that led to their development. In this section we will focus on this last point and show that Treme can be understood as a political act denouncing the ineptitude and corruption of the city's authorities, the unreliable policing, and the inadequate and haphazard government response.

3.1. Creighton Bernette: the voice of outrage

\footnotetext{
${ }_{28}^{28}$ Eric Overmyer, interview by authors, New Orleans, December 10, 2010.
} 
Creighton Bernette, the English professor and blogger played by actor John Goodman, is one of many voices trying to be heard in the screaming deafness of post-Katrina New Orleans. His motivation to help himself, his family and his community to return to the way things were before Katrina is relentless.

He weaves common sense solutions and heartfelt sentiments around a string of obscenities, aimed at a world that refuses to put politics aside for the people they are supposed to serve and protect 29 .

Creighton Bernette's voice is not his own. It refers to the opinions of professor and blogger Ashley Morris ${ }^{30}$ who represents the voice of the city. The audience is introduced to Creighton Bernette as he is being interviewed by an Australian journalist on the riverfront in episode 1 . The journalist gives voice to questions raised around the world, such as whether the city should be rebuilt, whether the levees were intentionally bombed to flood poor neighborhoods and protect upper class homes, and whether the culture warrants being restored. He becomes so outraged by the implication that the city isn't worth rebuilding that he throws their microphone into the river and then wrestles to do the same with the camera.

The most explicit critiques of the Federal response are indeed voiced through Bernette. He insists that the flooding is due to mistakes made by the federal government (Army Corps of Engineers) in building the levee system, a system that was supposed to protect its citizens. In episode 1, Bernette becomes agitated every time he hears the August 2005 flooding described as a 'natural' disaster to the point where he explains "The flooding of New Orleans was a man-made catastrophe, a Federal fucking fuck of epic proportions and decades in the making ${ }^{31}$." This instutional responsibility has been officially recognized by the Army Corps of Engineers when they acknowledged their own incompetence in securing levees, admitting that the levees it had built in the city were an incomplete and an inconsistent patchwork ${ }^{32}$.

In addition to voicing New Orleans' frustrations, Bernette's character provides a link to the outside world. In episode 4 Creighton films his own YouTube video, responding to those who have questioned

29 Danny Gallagher, "Meet Ashley Morris, the Real Creighton Bernette from Treme", The Times Picayune, June 12, 2010.

30 Dave Walker, "Meet with the real New Orleanians who inspired the characters in HBO's Treme", The Times Picayune, Friday, April 09, 2010.

${ }^{31}$ Dave Walker, Ibid.

${ }^{2}$ John Schwartz, "Army builders accept blame over flooding - Americas", The New York

Times, June $1^{\text {st }} 2006$. 
whether New Orleans is worth saving, and signs off with, "Fuck you, you fucking fucks33."

In episode 7 we see Creighton who unsuccessfully tries to resume work on a novel about the 1927 flood of New Orleans but instead he films a new YouTube rant about "Katrina fatigue". This online posting serves to broadcast a highly emotional challenge to the official accounts issued by the Bush Administration, The Federal Emergency Management Agency (FEMA), and the federal office of Homeland Security. Communicating through blogging on the internet gives him the opportunity to express his outrage, to scream his bitterness, and to find a way to exorcise his malaise.

Unable to sustain the stress and depression triggered by the destruction of his beloved city, Creighton Bernette eventually takes his life (episode 9). Columnist Chris Rose describes Bernette as, "one of the voices in the wilderness, raging at the machine, tilting at windmills and fighting for everything New Orleans, his New Orleans, my New Orleans. Defending her until death34."

\subsection{LaDonna Batiste Williams: the voice of loss}

LaDonna, played by actress Khandi Alexander, is the owner of a bar damaged by the storm. She is another voice expressing the frustration and anger of a community unable to move forward because of the slow response of the Federal Emergency Management Agency (FEMA) in rebuilding the city. One would expect that Federal agencies, such as FEMA and the Small Business Association (SBA) to name a few, would provide quick and efficient help. Unfortunately, they became major obstacles to the recovery process and added to the ordeal felt by the New Orleans residents. Chris Rose refers to the nightmare that people had to endure before starting the recovery process with the following poetry:

In Refrigerator Town, while all the poor folks drowned FEMA and Mike Brown were stuck on stupid.

In Refrigerator Dome which was temporary home,

To the terrified and downtrodden masses,

In Refrigerator Dome, the people waited alone

33 This title is one of the notable messages posted by Morris on November 2005 in which he expressed his rage against the people and organizations that disappointed him. Cf Ashley Morris: the blog, Fuck you, you fucking fucks, November 27, 2005,

$<$ http://ashleymorris.typepad.com/ashley_morris_the_blog/2005/11/fuck_you_you_fu.h tml>, consulted March 23, 2011.

34 Chris Rose, "We'll miss the blogger next door", The Times Picayune, Wednesday, April

16, 2008. 
While the buses showed up slower than molasses35.

Not only was everything destroyed and work and money made scarce by the storm, but the sluggish and inconsistent response of insurance companies added to the burden of the residents' predicament. While many people were covered by the Federal Flood Insurance program required by mortgage lenders, those who owned their homes outright or who lived in never-before flooded areas were not required to have flood insurance. Commercial Homeowners' Insurance only covered damage done by wind, not rain or flood water as the character LaDonna and her husband Larry Williams articulate in episode $3^{36}$. After he returns from a meeting with the insurance adjustor, Larry responds to LaDonna's question about how the meeting went, "Total run around. He says they still have to make a determination. If its wind damage they pay one way. If its flood damage they pay another. It's confusing as hell." Not anticipating such large-scale damage, little infrastructure existed for determining the fairness of insurance claims. Many homeowners found that the only coverage they had went to their mortgage lender, leaving no money for repairs 37.

LaDonna also voices a common problem triggered by the Operation Blue Roof program. This operation was developed by FEMA for the purpose of allowing homeowners to mitigate additional damage resulting from rain by having the U.S. Army Corps of Engineers contract roofers to install (blue) plastic tarps over the damaged areas of their roofs 38 ". While FEMA was willing to pay for the temporary fix, few trustworthy, competent roofers were available. LaDonna's interactions with the roofer Riley carry the frustrations held by many as the flimsy tarps were not meant to last months or years. He says,

RILEY. "We'll start on it this week Miss LaDonna, guaranteed."

LADONNA. "I been hearing that. You know what else I hear? That god damn blue plastic tarp flapping around my roof; I hear it in my sleep. When you gonna start it for real?" (Episode 2)

In scene after scene, whenever the camera moves back for a long shot, more evidence of housing damage like the ubiquitous blue tarp is revealed.

\footnotetext{
35 Chris Rose, 1 Dead in Attic: After Katrina, New York: Simon \& Schuster Paperbacks, 2007, p. 105.

${ }_{36}$ Mark Mese, "Insurance Claims after Hurricane Katrina (09/7/200)", LouisianaLawBlog, < http://www.louisianalawblog.com/business-and-corporate-insurance-claims-afterhurricane-katrina.html >, consulted April 22, 2011.

${ }_{37}$ Mark Mese, ibid.

${ }^{8}$ Operation Blue Roof, FEMA, October 26, 2004

< http://www.fema.gov/news/newsrelease.fema?id=14614>, consulted April 22, 2001
} 


\subsection{Albert Lambreaux: the voice of injustice}

The character Albert Lambreaux played By Clarke Peters, in addition to being Big Chief of a Mardi Gras Indian tribe, is also a master carpenter who can see first-hand the amount of rebuilding that will be needed in the neighborhoods. Lambreaux is a complex character, and it is through him that the audience learns about the public housing situation as well. After learning that his neighbor is squatting in the Calliope Housing Project he visits the project and talks with the security guard hired to watch the buildings. The security guard says,

GUARD. "We had squatters. Run 'em off."

LAMBREAUX. "It ain't cheap. All this security, spend all this money just to seal these up?"

GUARD. "I know."

LAMBREAUX. "People want to come home. There's no place to live."

GUARD. "You know they've been wanting to tear these projects down for years."

LAMBREAUX. "Now when there's a crying need. Calliope didn't take much water."

GUARD. "Most of them didn't take none."

LAMBREAUX. "Stood up to the wind just fine. You know when these was built? The Forties? They've been through some hurricanes. It makes no sense."

GUARD. "Nope."

LAMBREAUX. "But what does these days?"

Albert later presses a city council member, Ron Singleton, about the closing of the project since neither Katrina nor the subsequent flood seriously damaged the complex. Singleton tells him that reopening the projects isn't up to him (episode 5).

These sequences refer to post-Katrina proposals for the demolition and redevelopment of public housing. Before Katrina, the Calliope neighborhood was home to 1,400 African American working class households in 1,546 units, the third largest housing development in Louisiana ${ }^{39}$. Most of the complex was undamaged by Hurricane Katrina or the subsequent flood. Although many evacuated residents planned to return to public housing, the Housing Authority of New Orleans (HANO) ordered them not to move back, but to clear out their possessions ${ }^{40}$. In news accounts, HANO spokespeople expressed concerns about "looting, troublemakers, and squatters ${ }^{41}$ " For most

39 Dave Walker, Ibid.

${ }^{40}$ Jordan Flaherty, Jennifer Vitry, Loss and Displacement at the Calliope, Left Turn, January 11, 2006.

${ }^{41}$ Jordan Flaherty, ibid. 
journalists, the post-Katrina reconstruction constituted what scholar Benjamin Ansfield calls "modes of socio-spatial purification 42 " in a city known to be one of the most segregated metropolitan areas in the country.

In addition to bringing attention to the intended elimination of the housing projects in the city, Albert Lambreaux's voice in raising issues about injustice extends to the inability of poor people to rebuild. In a scene from episode 3, the Chief accompanies Lorenzo, one of the Indians, and son of a close friend, to inspect his family home in the lower $9^{\text {th }}$ Ward, decribed by a Washington Post columnist as, "the poorest of neighborhoods 43 ."

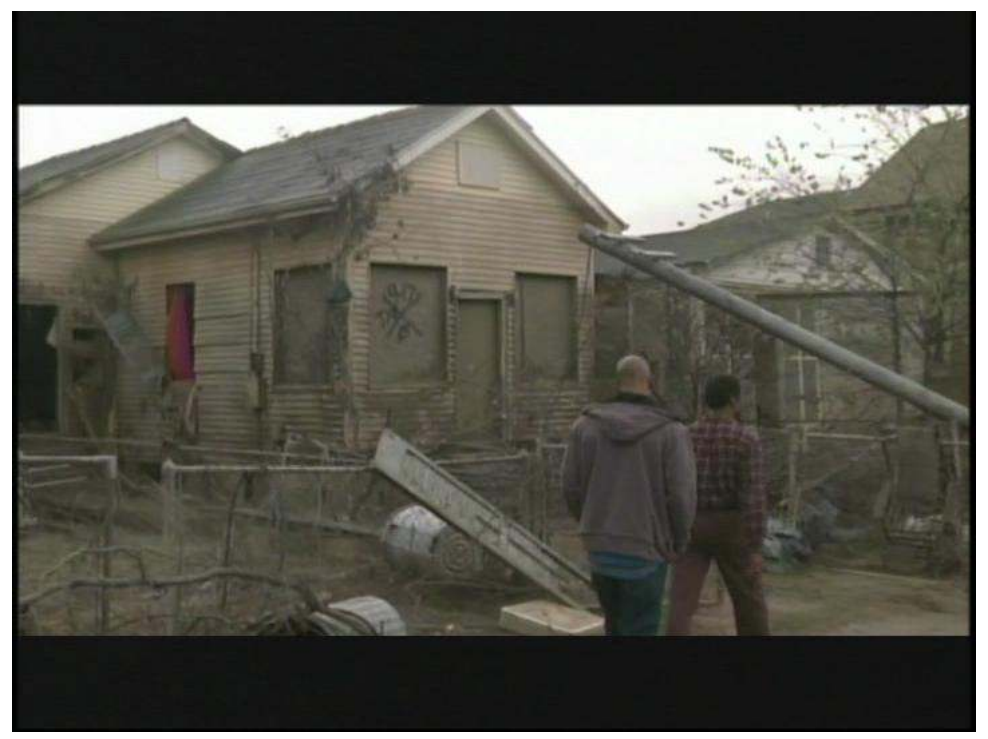

As the scene unfolds, there is debris strewn everywhere, left where the storm put it. No clean up has begun. They silently enter the building to inspect it:

LAMBREAUX. "Structurally it looks solid, still on its foundation at any rate. But that mold. I don't know."

${ }^{42}$ Benjamin Wynne Ansfield, Trough Murky Waters: Katrina, Public Housing, and the Cartographies of Struggle, Wesleyan University, May 2008.

43 Manuel Roig-Franzian, "Once More, a Neighborhood Sees the Worst'”, The Washington Post, September 8, $2005<$ http://www.washingtonpost.com/wp-

dyn/content/article/2005/09/07/AR2005090702127.html>, consulted February 22, 2010. 
LORENZO. "I hear they got plans for the Lower Nine. They're gonna bulldoze all of it. Then give the land to developers."

CHIEF LAMBREAUX. "That's why you need to come back. They can't bulldoze nothin' if the homeowners don't allow it."

LORENZO. "Who's going to stop them?"

LAMBREAUX . "Your father would understand what I'm talking about. Jesse would know."

LORENZO. "How to stop a bulldozer?"

LAMBREAUX. "Motherfuckers think people won't fight. Most won't. But some will."

Through this exchange the two characters voice concern that political interests will overwhelm homeowners, and that whole neighborhoods might not be allowed to rebuild unless individuals like himself, a Mardi Gras Indian, take the lead as many before him did to resist the incursion of outsiders who want to change their community.

3.4. Toni Bernette and the dysfunctions of the police and prison systems

Toni Bernette, played by actress Melissa Leo, is a civil rights lawyer who works on behalf of the poor, people of color, and the disenfranchised. Referencing Mary Howell, a real civil rights attorney, Toni voices the tensions between the local residents she represents and the authorities. Toni's interactions with police officers illustrate the problems that exist between those who want justice and others who seemingly ignore it. These tensions appear in episode 1 when Toni runs into a New Orleans police officer and sheriff's deputy having lunch at a restaurant. Each officer takes a different attitude toward her, evident in their conversation. While the deputy engages her in a casual conversation, the police officer freezes her out and calls her a "fuckin' cunt" behind her back, holding a grudge because she sued him the year before.

Toni links several characters to three police-related issues in the first season. The first issue deals with violation of civil rights, the second focuses on police brutality, and last, the breakdown of the prison system. These issues arise in the context of a city that was under Martial Law which imposed mandatory night time curfews, closed neighborhoods, and triggered the near suspension of local law enforcement. The violation of civil rights incident emerged in a scene in episode 3 where Davis McAlary, played by actor Steve Zahn, was arrested for bad mouthing the National Guard, and is bailed out by Toni. In the New Orleans jail with Toni, Davis explains:

"Violation of my civil rights [...] all I'm doing. We're talking holding a couple of beers. A jeep rolls up, Louisiana National Guards. The guy says to us, 'pour those out' I said 'dude, seriously, what part of 


\begin{abstract}
Louisiana are you guys from? We invented the go-cup. We invented the drive-through daiquiri shop."

TONI. "They stopped you for an open container? That law's not even on the books anymore." [...]

DAVIS. "No I'm pissed off. For four months I've had an army of occupation rolling through my neighborhood. On the side of the jeep it says 'military police' I said 'Do I look like military to you motherfucker? You can't police me."”

ToNI. "This town is barely hanging on. Cops are wound tight. Guards are on edge. You can't push it, alright?"

DAVIS. "We're the ones getting pushed."

TONI. "Davis, you do not motherfuck the National Guard."

DAVIS. "I just want my city back."
\end{abstract}

This exchange illustrates the National Guard's lack of knowledge about local laws pertaining to drinking behaviors in public and their intimidating methods of applying order. Indeed, after nearly 15,000 National Guard troops moved into New Orleans, it is reported that Louisiana Governor Blanco warned that the troops were "locked and loaded" sending a message of terror that resulted in containment through curfews, checkpoints, and intimidation 44 .

In a more serious vein, police brutality is staged when Toni represents the jazz musician Antoine Batiste, played by actor Wendell Pierce. Beaten and arrested by police for a minor incident late one night after a gig, he tells Toni he can't figure out why he was beaten; he was walking down the street and accidently bumped his "horn" against a police car: "Next thing I knew I had two cops wailing on me." Toni asks, "Were you resisting arrest?" Antoine replies, "Resisting? They didn't arrest me until after they kicked my ass." This exchange highlights the brutal police methods not unknown to black residents of the city. Local law enforcement was the focus of much criticism by local residents and in the local and national press. A case in point is the Danziger Bridge killings much discussed in the press which illustrates the mis-actions of the police against the citizens of New Orleans, in particular against African Americans who were attacked when they tried to cross the bridge to leave the flooded city 45 .

The relationship between Toni and LaDonna expresses the total breakdown of the prison system in New Orleans as Toni tries to cut through the red tape and find LaDonna's younger brother Daymo, wrongly arrested prior to the storm and evacuated from Orleans Parish Prison (OPP) to another parish prison. The Treme series alludes to the fact that Daymo may have been a victim of identity theft from a more

44 Critical Resistance, Amnesty for Prisoners of Katrina

<http://www.criticalresistance.org/katrina/why amnesty.pdf >, consulted May 21, 2011 45 Campbell Robertson, Charges Filed in Katrina Inquiry. <http://www.nytimes.com/2010/02/25/us/25orleans.html? r=1 >, consulted April 22, 2011. 
powerful inmate. From various conversations the audience learns also that there are no records of prison transfers, no evidence to prove guilt or innocence, and no motivation from anyone to untangle the situation. Early in episode 2, Toni refers to Daymo's case with colleagues. A photo of Daymo grounds the conversation during a meeting about who went where from OPP. Toni says, "all the records are under water." A colleague says, "They have been going parish by parish filing motions to compel the sheriffs to provide the names of all OPP prisoners in their custody." Later in the exchange another colleague states, "It's not like they kept track of who went where." Toni mentions that the family hasn't heard anything from him.

The story of Daymo's incarceration plays out slowly, unfolding across the entire first season as Toni determinedly pursues every lead. Through her the audience learns that officials largely serve their own agendas and that few people are in a position to do the right thing. The system is exploited at every turn, from the prisoners themselves who figure out how to manipulate the wrist bands with the more powerful prisoners taking advantage of weaker ones to gain early release, to other parish officials who benefit from money paid to hold OP prisoners. And everyone seems to want to save face by ignoring the obvious dysfunction. Daymo's story refers to the mandatory evacuation order for Orleans Parish which excluded "[e]ssential personnel of the Orleans Parish criminal sheriff's office and its inmates 46 ." On the day Hurricane Katrina hit, OPP held 6,375 prisoners; 60\% of them were held on minor municipal charges and a third were remanded as pretrial detainees according to the Sheriff's statistics and about 8,000 prisoner-evacuees according press reports 47 . As the water rose in the prison building deputies deserted en masse leaving behind prisoners in locked cells. Inmates spent days without power, food or water. The Deputies who were left at the jail were aware that there was no evacuation plan in place and were in a predicament 48 . They were outnumbered and understaffed to protect the prisoners. When they were first shipped to the Interstate Overpass (the highest point above water) the prisoners waited for days in the heat and finally had to be evacuated by bus to other jails. As a result of unprepared evacuation

\footnotetext{
${ }^{46}$ Transcript of CNN Coverage of Press Conference, Aug. 28, 2005 $<$ http://transcripts.cnn.com/TRANSCRIPTS/0508/28/bn.04.html $>$, consulted February $25,2011$.

47 Gwen Filosa, "Suspect Lost in Court System; Stuck for 10 Months, She Gets Out Today", The Times Picayune, June 12, 2006; Henry Weinstein, "Katrina's Aftermath; Justice System Faces a Deluge of Challenges", Los Angeles Times, September. 11, 2005

${ }^{48}$ R. P, interview by author, May 12, 2006 in Abandoned and Abused, American Civil Liberties Union (ACLU),

<http://www.aclu.org/files/pdfs/prison/oppreport20060809.pdf >, consulted March 13, 2011
} 
many of them, like Daymo in the series, hadn't been identified six months later49.

\section{The Economic Project}

Just as characters voice the political project, they also voice the economic quagmire affecting New Orleans in the aftermath of Katrina. Each episode features businesses opening and closing, money earned and spent. Because the program is about the music and culture of New Orleans, the businesses featured have cultural significance. They include restaurants and bars, taxi rides, funerals, performance venues, and recording opportunities and any other means people find to make money. While most of the city flooded, some neighborhoods were unaffected by the flood. Some businesses, particularly those in the French Quarter, remained open for business. For example, many club owners on Bourbon Street did not suffer damage like other businesses in the inner city ${ }^{\circ}$. Others who lost their regular customers were able to go on catering largely to first responders, police and firefighters, the National Guard and the Sheriff's Department for months after the storm. As the Treme narrative unfolds, we are invited into the workplaces and we observe the working conditions of New Orleans in late 2005. The purpose of this section is to show that Treme's political act of denunciation extends to the economic struggle of the food industry and the economic hardships experienced by the musicians who stayed in the city in contrast to those who achieved success by leaving.

\subsection{Janette Desautel: the voice of economic struggle}

The state of the food culture and businesses in the aftermath of Katrina are referenced in Treme through the character of Janette Desautel. The fictional Ms. Desautel-played by Kim Dickens-is an upand coming chef who owns the Uptown restaurant Desautel's. The creators of the series turned to notable New Orleans chef Susan Spicer as a consultant 5 . "[Janette Desautel] is inspired by her but she is not a model of her" says Eric Overmyer ${ }^{2}$. More important than portraying real people with accuracy, Treme emphasizes the daily difficulties of

${ }^{49}$ Amber McIlwain, “Abandoned Behind Bars: Hurricane Katrina’s Prisoners”, The Times, October 17, 2006.

${ }^{\circ}$ Chevel Johnson, "New Orleans' musicians keep busy Post-Katrina”, ABC News,

November 252010.

${ }^{51}$ Pervaiz Shallwani, “Portraying New Orleans Cuisine”, The Wall Street Journal, May 25, 2010 .

$5^{2}$ Eric Overmyer and Lolis Eric Eli, "Portrayal of a Living Culture", (Communication Events Week at Xavier University of Louisiana, New Orleans, April 13, 2011). 
the food industry and the uncertainty of preserving New Orleans food culture.

In episode 1 Desautel's restaurant is introduced when Janette confers with her sous chef Jacques on the politics of running a kitchen with disruptions in labor and food supply. The lack of cash is another disruption in the running of her restaurant. In the second episode (season 1) she explains her financial problems to her parents. She tells them that she is behind in her payments because she cannot be fully staffed or open full-time. The following scene has her strategizing with Jacques on how to handle the unpaid bills. As her plan develops she tells Jacques, "Pay Cusimano, buy dairy at the farmer's market, and we'll start washing our own tablecloths." In another scene of episode 3 her meat supplier makes an appearance and Janette greets him and then asks,

"What's going on? You got that check from me last month?"

HARVEY. "I did, but I've got some bad news [...] I'm going to have to put you on week to week."

JANETTE. "Three years I've been buying meat from you. Never late a payment but this one time".

HARVEY. "I'm sorry, darling but I just can't carry you. It's going to have to be pay as you go, week to week. I'm sorry."

Other restaurant owners experienced greater financial losses than Janette. According to Tom Weatherly, Vice President of Communication and Research for the Louisiana Restaurant Association (L.R.A.), most of the restaurateurs didn' t have time to wait for the insurance company to come up with a check and were putting all their life savings and their energy into their businesses 53 . Before Katrina, according to the L.R.A, the restaurant industry was the state's largest employer. About $10 \%$ of the workers of New Orleans were part of this industry, representing about 55,000 people and 3,400 restaurants. The Hurricane temporarily destroyed this industry which struggled to recover. As of December 2005, 21 percent of the food establishments had been issued permits to re-open. In February 2006, it had increased to 35 percent54. For some, Katrina was a financial loss, for others, like Janette Desautel, it was a daily struggle.

4.2. The Musicians: voices of struggles and success

Eric Overmyer and David Simon emphasize the difficulties the musical culture of New Orleans faced in sustaining itself. In an interview given in December 2010, Overmyer stated "[The series] is

53 "Can the restaurants save us?", The Times-Picayune, Living section, December 28, 2005. 54 Kim Severson and Julia Moskin, "Crawfish Etouffée Goes Into Exilee”, The New York Times, Spetember 6, 2005. 
primarily about the [musical] culture of New Orleans [...]" and later added, "It is difficult to make a living for musicians living here55." Musicians are at the heart of the Treme narrative. Their presence creates a context for the fictional characters by association, illustrating a range of musical careers, lifestyles, and economic circumstance.

\section{Sonny and Annie: busking for change}

An important context of Treme is street life in the French Quarter. The classically trained violinist Annie Tee (played by real violinist Lucia Micarelli) and the Dutch piano player Sonny (played by Michiel Huisman) represent relative newcomers to the city. As a streetmusician couple, they earn their meager living performing on the streets of the French Quarter.

They first appear in episode 2, busking for change on a French Quarter sidewalk. Playing for change can be lucrative when tourists abound, but after Katrina the lack of a tourist base and local population that constituted the main audience for street musicians dwindled, making the music industry unable to support talented street musicians ${ }^{56}$. Sonny and Annie are struggling as seen in the following exchange (episode 3). Tom McDermott a real musician playing himself walks up to Annie and says: "Hardly any tourists here. I guess we're going to have to wait for New Year's." They, along with many other more permanent musicians, have a far-from-secure economic arrangement. Sonny and Annie's story explains that New Orleans musicians' future really depends on their true abilities. Early in the series, the gap between the two musicians' talents appears obvious when other musicians point out Annie's talent (episode 2). While Sonny, convinced of his talent and his dream, decides to head to Texas, thinking that he may have better luck getting on the bill with real players after the storm (episode 4), Annie, who is overtalented, is invited to play with great musicians and bands in well-known bars. Sonny and Annie's characters also illustrate the street musician talent stratification as they can range from somewhat acceptable to excellent. "By New Orleans' musicians' standards, she's upwardly mobile and has a shot at greatness 57 ". In the series, she progressively starts to crossover from street musician status to club musician with a chance at recording, the fate of real and very talented musicians in the city.

55 Eric Overmyer, Ibid

${ }^{5}$ Bring New Orleans Back Commission, Post-Katrina Economic Redevelopment Plan,

City Of New Orleans, January 2006, p.66 <

http://www.nolaplans.com/plans/BNOB/Economic\%2oDevelopment\%20Committee\%20A

ttachment\%20F.pdf $>$, consulted April 10, 2011

57 Samjasper, Music Class/Layers of Treme \#1, Blogging Tremé,

<http://backoftown.wordpress.com/2011/04/16/music-classlayers-of-Treme-1/>

consulted February 23, 2011. 


\section{Antoine Batiste: hustling for gigs}

The trombone player Antoine Batiste played by actor Wendell Pierce does not fare much better than Sonny and Annie in making a living. He constantly searches for his next gig to improve his economic situation. The audience becomes aware of Antoine's economic situation during the first episode in which he negotiates several cab fares throughout the city as he goes from gig to gig, having lost his car during the storm.

Antoine Batiste's first appearance takes place when he arrives late to a second line funeral parade, for which he will earn $\$ 40$. Definitely known and respected by his fellow musicians he plays with Kermit Ruffins and gets hired to record with Allen Toussaint. The latter is a famous jazz musicians who has collaborated with other artists, such as Elvis Costello, The Rolling Stones, The Who, Aaron Neville and Dr. John to name a few ${ }^{8}$. Yet Antoine is always looking to make money. Through several episodes we see him scrambling for gigs everywhere in the city. He performs at a boring Mardi Gras ball, at the airport with a band of unemployed musicians, and on Bourbon Street (episode 6), leaving aside his pride as shown in the following exchange with a musician at the Old Point Bar in Algiers: "I heard about something on Bourbon Street." Antoine asks, "Bourbon Street?" The musician answers, "There's pride on Bourbon Street." This interchange suggests that wherever Antoine worked before the storm was probably no longer viable employment, and that he is left accepting a gig at a Bourbon Street strip club (episode 2), a street considered a tourist location and judged negatively by most local musicians.

In other scenes, after his trombone has been confiscated by the police, one Japanese Jazz fan buys him a brand new trombone and gives him a wad of cash (episode 5) revealing the historical truth that musicians were hardly able to survive economically using their talents. Indeed, after the storm, Japanese fans were important contributors to the Katrina recovery sending musical instruments and donations to students and musicians 59 .

Antoine Batiste's economic predicament was shared by other local musicians, since the decrease in visitors to the city from 10.1 million in 2004 to 3.7 millions in $2006^{60}$ resulted in the closing of

\footnotetext{
${ }^{8}$ Allen Toussaint and Friends, <http://allentoussaint.com/>, consulted May 15, 2011. 59 "Japanese Musician and Jazz Lover Gives Back to New Orleans, 'Beyond Katrina' contributor donating instruments", $P R W E B$, December $5,2006,<$ http://www.prweb.com/releases/2006/12/prweb487315.htm >, consulted February 22, 2010.

${ }^{60}$ Grace Wilson, New Orleans Tourism Industry report, $2^{\text {nd }}$ Quarter 2008/3 ${ }^{\text {rd }}$ Anniversary of Hurricane Katrina, August 29, 2008,
} 
performance venues, concert halls, and recording studios. Further, in January 2006, the number of days of operation per week was still limited because "promoters are cash strapped and are scaling-down concerts and festivals to meet lower tourist and local population audience size ${ }^{61}$ ". Finally, the number of gigs was at around $50 \%$ of the pre-Katrina level-from 12 gigs to six per month and earnings per gig had declined to $63 \%$ of the average pre-Katrina wages ${ }^{62}$. These stastistics testify to the dramatic loss in job opportunites for musicians after the storm.

\section{Delmond Lambreaux: the voice of success}

In contrast to other musicians, the character of Delmond Lambreaux played by Rob Brown illustrates a successful musical career. He is the son of Big Chief Albert Lambreaux and is an accomplished trumpet player. He finds himself drawn more to the music and atmosphere of New York than New Orleans.

He first appears while having a cell phone conversation with his sister Davina while he is in the middle of a gig at the Blue Note, a wellknown jazz club in New York City. In episode 1, he flies to New Orleans to visit and help his father survey the damage. In this scene, Delmond tells his father he had to cancel his gig in Boston. In the process of trying to help, his father tells him:

"If you're not going to help us load this truck, go down and pay the water bill. Get the water turned back on. Make yourself useful." DELMOND. "Wait, so you think I changed plans, cancelled gigs, came all the way down to pay the water bill on a bar we don't own? That's what you're thinking? Ahh right, that's what you're thinking".

Their interaction clarifies not only their conflicted relationship based on their different career paths, it also illustrates the gap existing between New Orleans musicians who never left, or wanted to leave the city, and those who left the city to have a better musical career. Many musicians like the Delmond character went to Chicago and New York following the early exodus of talented musicians such as Louis Armstrong and his mentor King Oliver ${ }^{63}$. Over time, these two cities have provided musicians with the opportunity to move away from street performances to become urban musical professionals playing in

$<$ http://www.neworleansonline.com/pr/releases/releases/Katrina3rdAnniversary_2nd QuarterTourismReportTWO.pdf>, consulted February 12, 2011.

${ }^{61}$ Bring New Orleans Back Commission, Post-Katrina Economic Redevelopment Plan, ibid p. 66.

62 Alex Rawls, "Sweet Home New Orleans", Offbeat.com, September 1, 2010, < http://offbeat.com/2010/o9/o1/sweet-home-new-orleans/>, consulted March 23, 2011

${ }^{6} 3$ Eric Overmyer and Lolis Eric Elie, Ibid. 
more sophisticated venues ${ }^{64}$ than the ones available in New Orleans, and offered them the training necessary to do business and improve their earning potential ${ }^{65}$.

New Orleans musicians' departure increased after the storm. Nearly 4,500 of New Orleans' musicians and music industry employees had been displaced to other locations across the US after Katrina, causing problems for forming musical groups. Further, along with the more vulnerable, older musicians, lacking basic resources to live, some younger artists who "might be more nimble at building new relationships and adapting to where the work is and who to talk to, had cultivated new opportunities to reach markets in other areas of the nation (especially those of national fame) ${ }^{66}$. Other very talented musicians like Troy "Trombone Shorty" Andrews, who plays himself in the series, were encouraged to develop more active touring careers.

A conversation between Delmond and his father (episode 2) highlights this gap between local musicians' attachment to traditional New Orleans jazz and the younger generation of musicians like Wynton Marsalis who broadened the boundaries of jazz in its contemporary form.

DELMOND. "I've got gigs. But I'll definitely be there Christmas day." ALBERT. "In and out like always. Couldn't ever stand to be around us for too long."

DELMOND. "Oh man, come on. It ain't like that. In fact I'm going to stay around a couple of more days. I've got a recording session (with) Toussaint."

ALBERT. "Toussaint, huh? You deigning to play local?"

DELMOND. "Yeah I'm deigning. I can play straight up New Orleans R\&B in my sleep."

ALBERT. "But can you swing? Not all you modern jazz cats can, you know."

DELMOND. "You sound like Wynton."

ALBERT. "I hope so."

In episode 3 Delmond, Trombone Shorty, and other musicians reflect on their attraction towards broader musical audiences and locations: "I love New York every time though. I'm glad I came up for this charity thing," says Trombone Shorty. To which Delmond replies:

\footnotetext{
${ }^{64}$ Kim Severson and Julia Moskin, ibid.

${ }^{65}$ Alex Rawls, "The State of Working Musicians in New Orleans: Half the Gigs ... and the Work Pays Less", Los Angeles Times, August 26, 2010.

${ }^{66}$ Brice Miller, in Antonio J. Garcia, "Jazz Education in New Orleans, Post Katrina", International Association for Jazz Education, Jazz Education Journal, Vol.39, $\mathrm{N}^{\circ} 3$, December 2006.
} 
If you dig New York, you ought to see Paris. There's a big world outside of New Orleans, Bro. To live there over in Europe, places where they actually respect musicians. You know what I'm saying? You blow better than half the cats in New York. If you was up here to live, ain't no telling how far you'd take it.

New Orleans musicians who chose to stay did not necessarily approve of those musicians' preference for professional careers outside of the city.

DELMOND. "Music is music. Doesn't matter where you live" TROMBONE SHORTY. "You don't miss home?

DELMOND. "In New Orleans they hype the music, but they don't love the musicians. A guy's got to leave to get their due. Pops, Prima, Wynton, the tradition is there, but they'll grind you down if you let them." (Episode 3)

Another musician adds, "I've been all over the world played any type of gig you can think of, but there's no place like New Orleans." In contrast to the "escapism" of musicians portrayed by Delmond and his inability to come back to New Orleans, others who are still displaced "may find a way back to New Orleans simply because they are culturally programmed for a life-style that only makes sense here." 67 Such is the case for Antoine Batiste.

\section{Discussion and conclusion}

The purpose of this article is to link fiction to reality through narrative alchemy at the service of political truth. Narrative alchemy is achieved through the cleverly interwoven individual characters and plot lines, all based on real people, real events and real narratives to create a meta-narrative. A meta-narrative is a grand narrative, constructed of small stories, anecdotes, oral histories, pictorial histories and written narratives. In New Orleans and the Gulf Coast region affected by hurricane Katrina, there are thousands of such narratives. Some have been collected and used for projects like Spike Lee's film: When the Levees Broke: A Requiem in Four Acts (2006) and for HBO's Treme. Other narratives have yet to be collected, and others never will be. The characters created thus represent the thousands of narratives-the meta-narrative-woven into plot lines for the program. This meta-narrative becomes the metaphor through which viewers' can apprehend the Political intention of the series.

${ }^{67}$ Bring New Orleans Back Commission, Post-Katrina Economic Redevelopment Plan, Louisiana, January 2006, p. 65. 
The program's creators have gone to extraordinary lengths to create believable characters and plot scenarios representative of lived lives and shared experiences, often nuanced with great detail. Our analysis reveals the realism of a city abandoned by federal agencies, the breakdown of its institutional system, and the economic struggle experienced by its more vulnerable citizens. These themes lay the foundations for the producers' intent to have viewers take a critical look at the political and economic situation of the city. In the context of these themes we conducted an in-depth analysis of the facts documenting this fiction linking historical truth with fiction.

The political intention of Treme can be interpreted through two speech acts as defined by Searle ${ }^{68}$. We propose to interpret the first act as an act of denunciation that can be identified within the political project and the second one as an act of testimony that can be identified within the economic project.

The first act, emerging out of our analysis of the political project is an act of denunciation which aims to designate collective responsibilities that led to the abandonment of the city after Katrina. This abandonment occurs on the screen through a realism of form staging a desolate landscape, dilapidated and surreal. But it also manifests itself in the narrative through the absence of public authority which, in the series, takes an ectoplasmic form. Apart from the correctional system and the New Orleans police, institutions are absent from the narrative reflecting the inertia of the Federal and State governments and the Bush administration toward the disaster and the lack of institutional and administrative organization. Through the characters of Creighton Bernette and his wife Toni and their feelings of anger, despair and injustice, we learn that the causes of the disaster are not of a natural order. They take the form of neglect and human error whether it is due to the fragility of the levees managed by the Army Corps of Engineers, the dysfunction of the prison and legal systems, the slowness and the ineptitude of the FEMA authorities in providing relief, or the inability of City Hall to respond to the disaster. Other responsibilities also relate to policy decisions taken against the residents of housing projects, projects systematically associated with poverty, crime, and unemployment. Albert Lambreaux's character highlights these decisions to close down public housing by the Housing Authority of New Orleans yet, remained perfectly livable despite the hurricane.

The second speech act of testimony is revealed through our economic analysis. This speech act is intended to showcase the resilience of New Orleanians in surviving their economic, social and professional demise in spite of a lack of all external aid. Through the relatively ordinary narratives of Chef Janette Desautel and the

${ }^{68}$ Searle, ibid. 
musicians, the creators of Treme show that the food and musical culture that made the reputation of the city is not something created for the tourism industry, but rather is a part of the daily sustenance of the resident of New Orleans. Further, this culture is an inherent part of the identity of the city. It can be a source of financial income, but, more so, it represents the soul of the city, the symbol and the embodiment of its strength and traditions. Treme is nothing more than an act of love and respect for the culture and the people of New Orleans, who derive their strength and engagement from the critique of the institutions which put the city in peril.

Therefore, Treme is both an act of denunciation and an act of testimony. Within the context of public space ${ }^{69}$, these acts emanate from a two-fold position on the part of the creators: one is a political position that is a critical stance of the collective, or the institutions, the other refers to a position of citizenry which defends the individual that is the people and their culture. Treme is a meta-act of political engagement.

${ }^{69}$ Jürgen Habermas, 1962. L'Espace public, Payot, Paris, 1978. 